\title{
Pengenalan Ekonomi Syariah dan Gerakan Mari Menabung Pada Siswa Sekolah Dasar
}

\section{Sharia Economic Introduction and Movement Come On Saving In Elementary School Students}

\author{
Dina Rahmawati ${ }^{1}$, Andri Brawijaya ${ }^{2}$ \\ ${ }^{1}$ Program Studi Ekonomi Syariah Fakultas Ekonomi Islam Universitas Djuanda Bogor, Jl Tol Ciawi \\ No.1,Kotal Pos 35 Bogor 16720, e-mail: dina.rahmawati@unida.ac.id \\ 2 Program Studi Ekonomi Syariah Fakultas Ekonomi Islam Universitas Djuanda Bogor, Jl Tol Ciawi \\ No.1,Kotal Pos 35 Bogor 16720, e-mail: andry.brawijaya@unida.ac.id
}

(Diterima: 25-06-2020; Ditelaah: 25-09-2020; Disetujui: 10-02-2021)

\begin{abstract}
Abstrak
Program pengenalan ekonomi syariah dan gerakan mari menabung pada siswa sekolah dasar merupakan kegiatan pengabdian kepada masyarakat dalam rangka meningkatkan pengetahuan masyarakat khususnya siswa sekolah dasar mengenai ekonomi syariah di Desa Cimanggu Satu Kecamatan Cibungbulang Kabupaten Bogor. Kegiatan ini berbentuk sosisalisasi edukasi yang dilaksanakan pada tanggal 20 Agustus 2019 di SDN Cimanggu 1. Tujuan dari kegiatan ini antara lain: (1) siswa-siswi sekolah dasar khususnya di SDN Cimanggu 1 dapat mengenal dan mengetahui ekonomi syariah serta penerapannya dalam kehidupan sehari-hari dan dapat mengaplikasikannya di keluarga dan lingkungan sekitar, (2) siswa-siswi sekolah dasar dapat termotivasi untuk memahami pentingnya menabung sebagai perencanaan dan persiapan akan masa depan. Ada beberapa langkah yang dilakukan untuk melaksanakan kegiatan pengabdian ini, yaitu (1) analisis situasi, (2) perancangan kegiatan, dan (3) pengimplementasian kegiatan. Program ini memberikan dampak kepada siswa siswi sekolah dasar yaitu bertambahnya pengetahuan mengenai ekonomi syariah dan pentingnya menabung.
\end{abstract}

Kata Kunci: Ekonomi Syariah, Menabung, SDN Cimanggu 1

\begin{abstract}
The Sharia economics Introduction Program and the let's save movement for elementary school students are community service activities in order to increase public knowledge, especially elementary school students about sharia economics in Cimanggu Satu Village, Cibungbulang District, Bogor Regency. This activity is in the form of education socialization which was held on August 20, 2019 at SDN Cimanggu 1. The objectives of this activity include: (1) elementary school students, especially at SDN Cimanggu 1, getting to know and know the sharia economy and its application in daily life and can apply it in the family and the surrounding environment, (2) elementary school students can be motivated to understand the importance of saving as planning and preparation for the future. There are several steps taken to carry out this community service activity, namely (1) situation analysis, (2) activity design, and (3) implementation of activities. This program has an impact on elementary school students by increasing knowledge about sharia economics and the importance of saving.
\end{abstract}

Keywords: Sharia Economy, Savings, SDN Cimanggu 1

\section{PENDAHULUAN}

Perkembangan ekonomi syariah tidak hanya terjadi di kota-kota besar saja namun saat ini juga gencar dilakukan di daerah pedesaan. Sasaran utamanya adalah masyarakat kelas menengah ke bawah. Begitupun dengan Desa Cimanggu Satu Kecamatan Cibungbulang Kabupaten Bogor yang mana terdapat peluang untuk mensyiarkan ekonomi syariah di desa tersebut. Pemberdayaan Sumber Daya Manusia (SDM) merupakan suatu 
aspek manajemen yang sangat strategis karena Sumber Daya Manusia merupakan daya yang bersumber dari manusia dan memberikan energi terhadap sumber lainnya dalam suatu manajemen (Idris, 2016:2). Adapun pemberdayaan ekonomi masyarakat dapat dilakukan dengan membantu dalam memotivasi melalui pemahaman dan pengenalan ekonomi syariah dalam kehidupan sehari-hari, untuk bersama-sama mengatasi permasalahan yang dihadapi melalui pemberdayaan masyarakat dengan meningkatkan kualitas sumber daya manusia yang ada.

Dijelaskan oleh kepala Desa Cimanggu Satu bahwa masih banyak masyarakat yang berprilaku konsumtif, hal ini menyebabkan masyarakat melakukan peminjaman uang kepada bank keliling. Pada kasus ini membuat keadaan perekonomian masyarakat Desa Cimanggu Satu menurun. Menurut Juliandi et.al. (2019:41) menyatakan bahwa selama lebih dari satu tahun dasawarsa ini semakin berkembangnya instansi ekonomi berbasiskan hukum islam, namun masih banyak umat islam Indonesia yang belum memahami dan mengenal perekonomian berbasis syariah secara menyeluruh.

Berdasarkan hasil survei yang telah dilaksanakan, maka merencanakan sebuah program untuk berusaha memecahkan permasalahan tersebut. Menurut Nabawiy (2019:71) dibutuhkan solusi-solusi cerdas untuk mengatasi penyakit yang bernama riba diantaranya adalah diawali dengan diri sendiri dan keluarga untuk menjauhi riba, serta dukungan dan upaya-upaya ekonomi syariah bebas dari riba. Kesadaran umat islam terhadap perekonomiannya sangat penting. Oleh sebab itu, melalui kegiatan ini diharapkan dapat menjadikan suatu upaya dalam meminimalisisr praktik riba di desa Cimanggu Satu.

Program pengenalan ekonomi syariah dan gerakan mari menabung di SDN Cimanggu 1 yang beralamat di Desa Cimanggu Satu ini diharapkan dapat menambah wawasan kepada para bibit unggul dan penerus bangsa khususnya penerus di desa Cimanggu Satu. Dengandiselenggarakannya kegiatan ini diharapkan siswa-siswi sekolah dasar dapat mengenal ekonomi syariah sejak dini, memahami penerapan ekonomi syariah dalam kehidupan sehari-hari dan kemudian senantiasa gemar menabung untuk mempersiapkan masa depan. Selain itu, yang paling penting diharapkan dapat memberikan kemajuan bagi Desa Cimanggu Satu di masa yang akan datang melalui kegiatan ekonomi dalam kehidupan yang berdasarkan pada syariat Islam. Hal ini dilakukan karena adanya potensi dan peluang untuk menghasilkan bibit unggul di masa yang akan datang di desa Cimanggu Satu kecamatan Cibungbulang Kabupaten Bogor.

\section{METODE PELAKSANAAN}

Beberapa langkah dalam pelaksanaan kegiatan pengabdian ini, yaitu :

1. Analisis situasi, adalah kegiatan pengumpulan data observasi serta melakukan pemetaan permasalahan

2. Perencanaan kegiatan, dilakukan setelah permasalahan diketahui dan dipetakan kemudian merumuskan solusi tepat yang akan diterapkan.

3. Pengimplementasian kegiatan, dilaksanakan sesuai rencana yang telah disusun, 


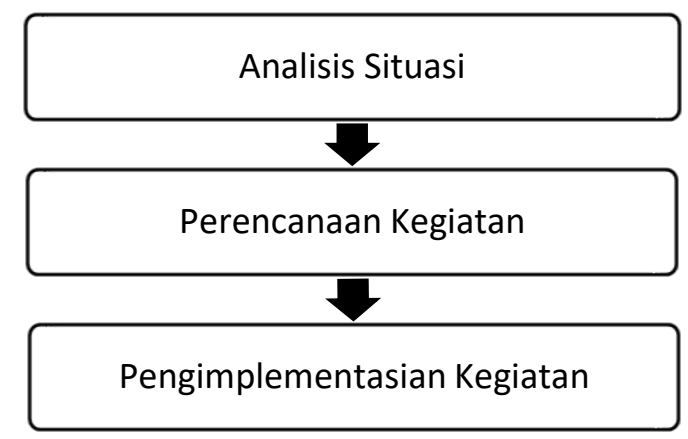

Gambar 1. Tahapan Pelaksanaan Kegiatan

Analisis Situasi

Desa Cimanggu Satu merupakan sebuah desa yang terletak di kecamatan Cibungbulang kabupaten Bogor, dengan luas wilayah $170 \mathrm{Ha}$, diatas permukaan laut 240 dpml dan tinggi curah hujan $236 \mathrm{~mm}^{3}$, suhu rata-rata $20 \mathrm{dc} \mathrm{s} / \mathrm{d} 32$ dc yang terbagi dalam 4 (empat) Dusun, 9 (sembilan) Rukun Warga (RW) dan 32 (tiga puluh dua) Rukun Tetangga (RT). Jumlah penduduk desa Cimanggu Satu secara keseluruhan berjumlah 9492 yang dirinci pada tabel 1.

Tabel 1.

Jumlah Penduduk Desa Cimanggu Satu Berdasarkan Jenis Kelamin

\begin{tabular}{|c|c|c|}
\hline No & Kategori & Jumlah \\
\hline 1 & Jumlah Laki-laki & : 4927 Orang \\
\hline 2 & Jumlah Perempuan & : 4565 Orang \\
\hline 3 & Jumlah Total & : 9492 Orang \\
\hline 4 & $\begin{array}{l}\text { Jumlah } \\
\text { Keluarga }\end{array}$ & : $2884 \mathrm{KK}$ \\
\hline 5 & Kepadatan Penduduk & : 0.02 Per km \\
\hline
\end{tabular}

Sebagian besar penduduk Desa Cimanggu Satu bekerja sebagai petani dan karyawan buruh swasta. Jumlah profesinya ada pada Tabel 2.

Tabel 2.

Jumlah Penduduk Desa Cimanggu Satu berdasarkan Mata Pencaharian

\begin{tabular}{|c|c|c|}
\hline No & Jenis Pekerjaan & Jumlah \\
\hline 1 & Petani & : 217 Orang \\
\hline 2 & Buruh Tani & : 468 Orang \\
\hline 3 & $\begin{array}{l}\text { Buruh } \\
\text { Perempuan }\end{array}$ & ; -Orang \\
\hline 4 & Buruh Migran Laki-Laki & : -Orang \\
\hline 5 & Pegawai Negeri Sipil & : 24 Orang \\
\hline 6 & $\begin{array}{l}\text { Pengrajin } \\
\text { Rumahan }\end{array}$ & : 21 Orang \\
\hline 7 & Pedagang Keliling & : 85 Orang \\
\hline
\end{tabular}




\begin{tabular}{llll}
\hline $\mathbf{8}$ & Montir & $:$ & 22 Orang \\
\hline $\mathbf{9}$ & Dokter Swasta & $:$ & 2 Orang \\
\hline $\mathbf{1 0}$ & Bidan Swasta & $:$ & 4 Orang \\
\hline $\mathbf{1 1}$ & Perawat Desa & $:$ & 3 Orang \\
\hline $\mathbf{1 2}$ & $\begin{array}{l}\text { Pembantu } \\
\text { Tangga }\end{array}$ & Rumah & : 15 Orang \\
\hline $\mathbf{1 3}$ & Tni & $:$ & 6 Orang \\
\hline $\mathbf{1 4}$ & Polri & $:$ & 1 Orang \\
\hline $\mathbf{1 5}$ & $\begin{array}{l}\text { Pensiunan } \\
\text { PNS/TNI/POLRI }\end{array}$ & $:$ & 9 Orang \\
\hline $\mathbf{1 6}$ & Dosen Swasta & $:$ & 2 Orang \\
\hline $\mathbf{1 7}$ & $\begin{array}{l}\text { Karyawan Perusahaan } \\
\text { Swasta }\end{array}$ & $:$ & 531 Orang \\
$\mathbf{1 8}$ & $\begin{array}{l}\text { Karyawan Perusahaan } \\
\text { Pemerintah }\end{array}$ & $:$ & 12 Orang \\
\hline $\mathbf{1 9}$ & Lain - Lain & $:$ & 8067 Orang \\
\hline & Jumlah & $:$ & $\mathbf{9 4 9 2}$ Orang \\
\hline
\end{tabular}

Sumber: Data Profil Desa Cimanggu Satu 2019

Fasilitas pendidikan di Desa Cimanggu Satu sudah sangat memadai, walaupun jumlah dan pelayanannya masih harus terus ditingkatkan. Tersedia fasilitas pendidikan mulai dari tingkat TK/RA sampai dengan SMA/MA yang jumlahnyadisajikan pada Tabel 3.

Tabel 3.

Jumlah sarana pendidikan di Desa Cimanggu Satu

\begin{tabular}{lll}
\hline No & Sarana Pendidikan & Jumlah \\
\hline $\mathbf{1}$ & TK/RA & 3 buah \\
\hline $\mathbf{2}$ & SDN & 3 buah \\
\hline $\mathbf{3}$ & SD Swasta & - \\
\hline $\mathbf{4}$ & MI & - \\
\hline $\mathbf{5}$ & SLTP & 2 buah \\
\hline $\mathbf{6}$ & SLTA & 1 buah \\
\hline $\mathbf{7}$ & Diploma/Perguruan & - \\
& Tinggi & \\
\hline $\mathbf{8}$ & BLK/Tempat Kursus & - \\
\multicolumn{2}{l}{ Sumber: Data Profil Desa Cimanggu Satu 2019 }
\end{tabular}

Masyarakat Desa Cimanggu Satu merupakan masyarakat yang sangat kuat kegiatan sosial serta kekompakannya. Salah satunya dalam hal kegiatan keagamaan. hal ini dibuktikan dengan budaya pengajian yang hampir setiap minggu diadakan dengan tempat dan ulama yang berbeda. Pengajian-pengajian tersebut dilaksanakan di mesjidmesjid yang ada di Desa Cimanggu Satu, dan kegiatan kerja bakti di setiap RT/RW yang selalu diikuti masyarakatnya dengan antusias. 


\section{Perencanaan Kegiatan}

a. Persiapan

Persiapan pelaksanaan program Pengenalan Ekonomi Syariah kepada Siswa Sekolah Dasar yang pertama adalah menggali informasi terlebih dahulu sekolah mana yang dapat dikunjungi dan dijadikan tempat pelaksanaan kegiatan. Setelah berdiskusi dengan Dosen Pembimbing Lapangan KKN, ketua dan peserta KKN yang lain, juga tokoh masyarakat sekitar maka dipilihlah SDN Cimanggu 1 dan tempat pelaksaanaan program. Persiapan selanjutnya kemudian peserta KKN selaku penanggung jawab program melakukan perizinan kepada pihak sekolah yang terkait mengenai maksud dan tujuan diselenggarakannya program tersebut.

b. Rapat

Rapat dilaksanakan pada tanggal 19 Agustus 2019 bersama ketua dan peserta KKN kelompok 5 lainnya dengan membahas materi yang akan disampaikan mengenai pengenalan ekonomi syariah dan gerakan mari menabung kepada siswa sekolah dasar di SDN Cimanggu 1.

c. Survey

Peserta KKN kelompok 5 Fakultas Ekonomi Islam melakukan survey untuk program pengenalan ekonomi syariah dan gerakan mari menabung pada siswa sekolah dasar yang dilaksanakan pada tanggal 13 Agustus 2019 dengan langsung menemui kepala Sekolah SDN Cimanggu 1.

d. Perizinan

Perizinan pelaksanaan program dilakukan bersamaan dengan survey yaitu pada tanggal 13 Agustus 2019 dengan langsung menemui kepala sekolah SDN Cimanggu 1. Perizinan tersebut dilakukan dengan tujuan menyampaikan maksud dan tujuan diselenggarakannya program yang bersangkutan dan untuk mendapat dukungan dari kedua belah pihak agar pelaksanaan program KKN berjalan sesuai dengan yang diharapkan.

e. Alur tahapan penyusunan program

Tahapan penyusun program KKN Kelompok 5 Fakultas Ekonomi Islam :

1) Peserta KKN dibagi ke dalam 5 bidang yaitu bidang ekonomi, keagamaan, sosialbudaya, pendidikan, sarana-prasarana.

2) Masing-masing bidang menentukan program KKN yang akan dilaksanakan.

3) Setelah menentukan dan memilih program, peserta KKN yang bersangkutan dengan masing-masing programnya menentukan sasaran dan tempat pelaksanaannya.

4) Melakukan perizinan, survey ke objek atau tempat yang direncanakan.

5) Mempersiapkan materi yang akan disampaikan, dan rundown acara dan teknik pelaksanaan kegiatannya.

Pengimplementasian Kegiatan

a. Lokasi Kegiatan

Kegiatan pengenalan Ekonomi Syariah dan gerakan mari menabung pada siswa sekolah dasar berlokasi di ruang kelas 5 SDN Cimanggu 1. 
b. Waktu Pelaksaan

Pelaksaan kegiatan program pengenalan Ekonomi Syariah dan gerakan mari menabung pada siswa sekolah dasar dilaksanakan pada hari Selasa, tanggal 20 Agustus 2019 pukul 11.00.

c. Sasaran

Adapun sasaran dari kegiatan ini adalah siswa-siswi sekolah dasar khususnya kelas 6 SDN Cimanggu 1.

\section{HASIL \& PEMBAHASAN}

Pengenalan ekonomi syariah merupakan salah satu program penting bidang ekonomi yang bertujuan untuk mensyiarkan ekonomi syariah ke semua kalangan dari mulai anak-anak, remaja, orang tua, dan tokoh masyarakat lainnya khususnya di Desa Cimanggu Satu. Pemahaman tentang konsep ekonomi Islam dan praktiknya dalam kehidupan sehari-hari juga harus diajarkan sejak dini kepada anak-anak sehingga di masa yang akan datang semakin banyak anak yang tumbuh menjadi ekonom Islam yang kuat, mahir dalam pengelolaan keuangan dan berjiwa bisnis. Dengan program pengenalan ekonomi syariah kepada lapisan pertama pendidikan yaitu sekolah dasar diharapakan menjadi bekal siswa-siswi sekolah dasar dapat memahami hal-hal apa saja yang berkaitan dengan ekonomi syariah khususnya dalam kehidupan sehari hari dan juga bisa mengembangkan kemandirian ekonomi syariah di lingkungannya. Dengan demikian taraf hidup masyarakat juga bisa terangkat.

Berdasarkan hasil dari analisis dan situasi di atas mengenai Desa Cimanggu Satu, maka solusi dari permasalahan tersebut adalah dengan melakukan pemberdayaan Sumber Daya Manusia (SDM) salah satunya yaitu dengan memberikan pengenalan sejak dini mengenai ekonomi syariah kepada generasi penerus untuk masa depan. Solusi permasalahan berupa pengenalan ekonomi syariah dan gerakan mari menabung pada siswa sekolah dasar merupakan sebuah strategi untuk mengenalkan praktik ekonomi syariah pada kegiatan sehari-hari yang mana akan menjadi pondasi untuk kegiatan ekonomi syariah ke lingkup yang lebih luas yaitu meminimalisir praktik ribawi dan bank keliling di Desa Cimanggu Satu. Kemudian dari pengenalan ekonomi syariah tersebut diaplikasikan juga dalam gerakan mari menabung pada siswa sekolah dasar sebagai aplikasi dari bibit unggul dan generasi muda yang pandai mempersiapkan bekal untuk masa depan. Jika pemahaman ekonomi syariah sejak dini dilakukan maka tujuan hidup sebagai manusia untuk mencapai kebahagiaan dunia akhirat akan terpenuhi.

Pengenalan ekonomi syariah dan gerakan mari menabung pada siswa sekolah dasar bertujuan untuk memberikan pengetahuan mengenai apa itu ekonomi syariah, halhal apa saja yang berkaitan dengan ekonomi syariah dan bagaimana menerapkan ekonomi syariah pada kehidupan sehari-hari. Dari pengenalan ekonomi syariah kepada siswa-siswi sekolah dasar maka dikaitkan dengan motivas-motivasi gerakan mari menabung kepada siswa-siswi peserta kegiatan yang mana menabung atau menyisihkan uang merupakan bagian dari ekonomi syariah. Sehingga dengan adanya gerakan mari menabung peserta KKN dapat memberikan pengetahuan tentang pentingnya menabung 
untuk masa depan, belajar hidup hemat dari sejak dini, dan menjelaskan manfaat dari menabung sehingga dapat memotivasi siswa-siswi sekolah dasar untuk memulai dan lebih rajin menabung.

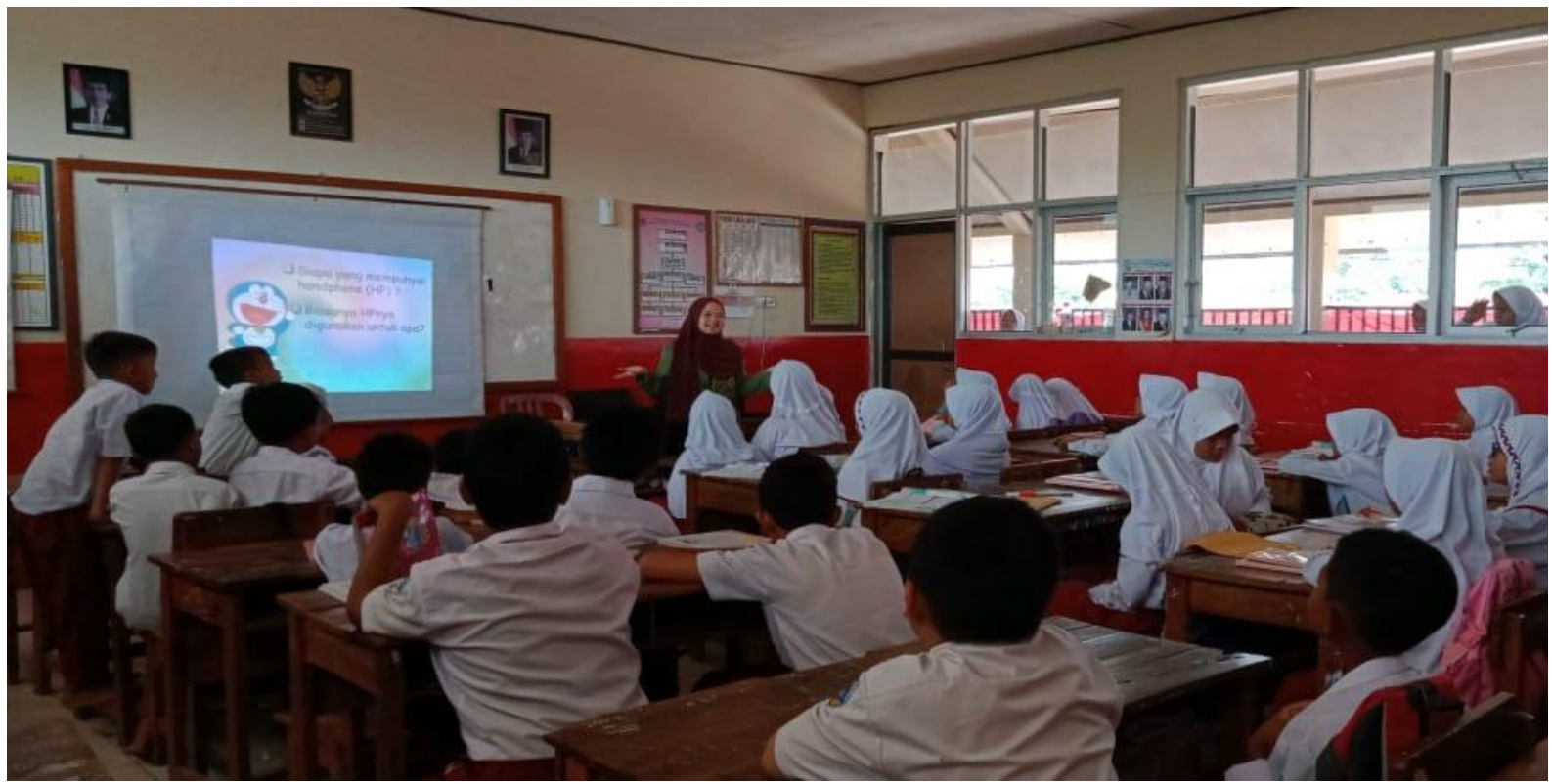

Gambar 2. Penyampaian Materi

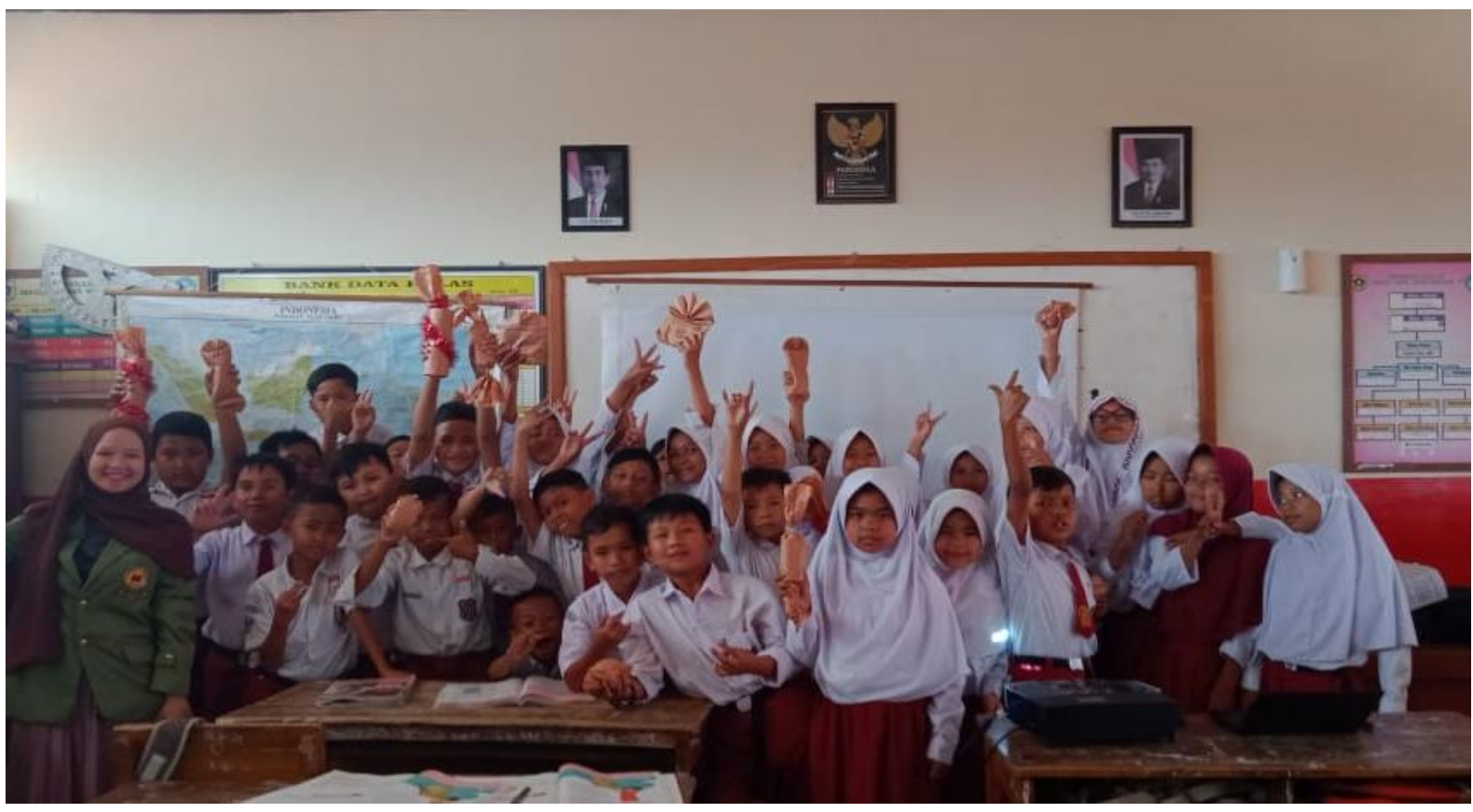

Gambar 3. Antusiasme Peserta dalam Kegiatan

Pelaksanaan kegiatan pengenalan Ekonomi Syariah dan gerakan mari menabung pada siswa sekolah dasar yang dilaksanakan di SDN Cimanggu 1 mendapatkan apresiasi dan antusias yang baik dari siswa-siswi maupun pihak sekolah tempat dimana kegiatan tersebut dilaksanakan. Kegiatan ini dilaksanakan di ruang kelas tertutup dengan menampilkan materi berupa powerpoint yang mampu memberikan efek fokus dan hal yang baru pada siswa-siswi sekolah dasar. Materi yang disampaikan diantaranya yaitu 
pengertian dasar ekonomi syariah, penerapan ekonomi syariah dalam kehidupan seharihari, manfaat menabung dan motivasi-motivasi untuk menumbuhkan rasa keinginan untuk menabung sejak dini, serta perencanaan dan cita-cita di masa depan yang dapat diwujudkan dengan terbiasa menabung sejak dini. Luaran yang dicapai dari kegiatan ini yaitu siswa-siswi sekolah dasar mendapatkan pengetahuan dasar tentang ekonomi syariah, mengingat bahwa sekolah dasar adalah lapisan pertama pendidikan yang mampu menjadi pondasi tumbuh dan berkembangnya pemikiran anak-anak. Menumbuhkan kesadaran betapa pentingnya menabung sejak dini dan banyak manfaat yang bisa didapatkan apabila kita terbiasa menabung dan menyisihkan uang jajan sejak dini.

\section{KESIMPULAN}

Pelaksanaan pengabdian masyarakat Universitas Djuanda Bogor yang dilaksanakan di desa Cimanggu Satu Kecamatan Cibungbulang Kabupaten Bogor berjalan sesuai dengan rencana yang telah disusun sebelumnya, dalam program pengenalan ekonomi syariah dan gerakan mari menabung pada siswa sekolah dasar, siswa-siswi SDN Cimanggu 1 mampu memahami apa itu ekonomi syariah dan penerapannya dalam kehidupan sehari-hari. Dengan dilaksanakannya program ini telah emmberikan pengetahuan mengenai apa itu ekonomi syariah, hal-hal apa saja yang berkaitan dengan ekonomi syariah dan bagaimana menerapkan ekonomi syariah pada kehidupan seharihari. Serta gerakan mari menabung sebagai implementasi dari ekonomi syariah yang bertujuan untuk membiasakan menabung sejak dini untuk perencanaan dan bekal masa depan. Dari kegiatan ini terdapat perbedaan yang signifikan antara adanya kehadiran dan sebelum adanya mahasiswa di lingkungan masyarakat dengan beberapa programprogram yang sudah terlaksana khususnya dalam bidang pendidikan.

\section{UCAPAN TERIMA KASIH}

Ucapan terimakasih kepada Fakultas Ekonomi Islam dan Universitas Djuanda Bogor yang telah memfasilitasi segala perijinan dan mendukung penuh untuk kegiatan pengabdian ini. Ucapan terima kasih ini juga disampaikan kepada Bapak Asep Sukardi selaku Kepala Desa Cimanggu Satu beserta jajarannya yang telah memberikan ijin dan mendukung penuh kegiatan pengabdian selama 30 hari. Ucapakan terima kasih juga untuk semua donatur yang telah membantu dan mendukung kegiatan di Desa Cimanggu Satu.

\section{DAFTAR PUSTAKA}

Abdusshamad, Saifullah. 2015. Ayat Tentang Distribusi Serta Relasi Kaum Kaya \& Miskin. Al-Jurnal Iqtishadiyah : Ekonomi Syariah Dan Hukum Ekonomi Syariah Volume: II, Nomor II. 
Kusmanto, Thohir Yuli. 2014. Pengembangan Ekonomi Islam Berbasis Kependudukan Di Perdesaan. Jurnal Ilmu Dakwah, Vol. 34, No.2.

Nordbaus D. William \& Samuelson A. Paul. 1993. Mikroekonomi. Edisi Keempatbelas. Erlangga. Jakarta

Notoatmodjo, Soekidjo, 2003, Pengembangan Sumber Daya Manusia, Jakarta:PT. Rineka Cipta.

Saefuddin, A M. 1987. Ekonomi Dan Masyarakat Dalam Perspektif Islam. Cetakan I. Jakarta: Rajawali;

Https://Www.Slideshare.Net/Wiku/Pengenalan-Ekonomi-Syariah-Wiku (Diakses Pada Tanggal 18 September 2019)

Http://Keuangansyariah.Mysharing.Co/Ekonomi-Syariah-Harus-Diterapkan-Di-

Sekolah-Umum/ (Diakses Pada Tanggal 18 September 2019)

Https://Id.Wikipedia.Org/Wiki/Cimanggu 1, Cibungbulang, Bogor (Diakses Pada 11 September 2019)

Https://Id.Wikipedia.Org/Wiki/Ekonomi Syariah (Diakses Pada 11 September 2019) 